\title{
Predicting Clinical Benefit in Non-Small-Cell Lung Cancer Patients Treated with Epidermal Growth Factor Tyrosine Kinase Inhibitors
}

\author{
L.C. Amler, A.D. Goddard, AND K.J. Hillan \\ Development Sciences, Genentech, Inc., South San Francisco, California 94080
}

\begin{abstract}
Erlotinib and gefitinib are small-molecule inhibitors of the epidermal growth factor tyrosine kinase. Erlotinib is approved for the treatment of locally advanced or metastatic non-small-cell lung cancer after failure of at least one prior chemotherapy regimen. Although it is active in unselected patients, clinical characteristics and tumor molecular markers associated with enhanced benefit have been identified. Notably, never-smoker status or a positive EGFR FISH test has been consistently predictive of greater erlotinib benefit. Other markers, such as EGFR mutations and EGFR protein expression, as determined by immunohistochemistry, and KRAS mutation status have not proven to be consistently associated with differential benefit.
\end{abstract}

The epidermal growth factor receptor (EGFR) is a receptor tyrosine kinase expressed in the majority of nonsmall-cell lung cancers (NSCLC) (Dazzi et al. 1989; Kaseda et al. 1989). The efficacy of EGFR tyrosine kinase inhibitors (EGFR TKIs) in preclinical tumor models, together with their favorable toxicity profiles, led to their clinical development in NSCLC and other solid tumors (Higgins et al. 2004). Erlotinib and gefitinib are smallmolecule inhibitors of the EGFR tyrosine kinase, which showed evidence of antitumor activity in patients with NSCLC as single agents (Lynch et al. 2004b). This activity was recently shown to translate to a significant survival benefit in a randomized phase III trial of erlotinib versus placebo (hazard ratio $[\mathrm{HR}]=0.73$ ) in second-/third-line NSCLC (Shepherd et al. 2005), whereas gefitinib failed to demonstrate a significant survival advantage in a trial of similar design ( $\mathrm{HR}=0.89)$ (Tamura and Fukuoka 2005).

Erlotinib's survival advantage in second-/third-line lung cancer was observed in an unselected patient population. However, it is possible that some patient subpopulations might derive greater benefit than others. Indeed, one hypothesis would be that patients whose tumors are most dependent on EGFR signaling for growth and survival would derive greatest therapeutic benefit, whereas patients with tumors that are functionally independent of EGFR would not derive benefit. In this review, we examine the molecular and clinical markers that have been shown to be associated with outcome in NSCLC patients treated with EGFR TKIs and we discuss how these are related to tumor dependence on signaling through EGFR.

\section{EGFR MUTATIONS PREDICT FOR RESPONSE FROM EGFR TKI THERAPY, BUT HAVE NOT BEEN ASSOCIATED WITH PROLONGED SURVIVAL}

Somatic mutations in the tyrosine kinase domain of EGFR were recently described in tumors of NSCLC patients who showed objective clinical responses (tumor shrinkage) to erlotinib (Pao et al. 2004) and gefitinib
(Lynch et al. 2004a; Paez et al. 2004) monotherapy. Patients with EGFR-mutant tumors were more likely to be never-smokers, females, and of Asian ethnicity (Lynch et al. 2004a). The frequency of heterozygous mutations varies according to the population being studied but has been reported to be approximately $10-12 \%$ in patients from the United States and 19-26\% in patients from Southeast Asia.

The most frequently observed mutations are in exons 19-22 of the EGFR gene, with approximately $90 \%$ being either in-frame deletions in exon 19 or a L858R substitution in exon 21 (Pao et al. 2004). Functional analysis of the mutant receptors in cell lines shows evidence of specific gain of function, with elevated ligand-dependent activation of the receptor. Furthermore, the mutants were inhibited by lower concentrations of gefitinib and erlotinib compared with wild-type EGFR (Lynch et al. 2004a; Paez et al. 2004; Pao and Miller 2005). Thus, EGFR mutations appear to define tumors that are dependent on EGFR signaling and that are responsive to EGFR inhibition.

Compared to wild-type EGFR, the mutant EGFR selectively activates the Akt and STAT signaling pathways, which support cell survival, but has no effect on ERK signaling, which induces cell proliferation (Sordella et al. 2004). Consistent with this observation, NSCLC cells expressing mutant EGFR undergo apoptosis upon treatment with EGFR TKIs, suggesting that mutant EGFRs selectively support tumor cell survival, on which NSCLCs become dependent. This could account for the higher frequency of objective tumor responses seen in patients with mutant EGFR-bearing tumors upon treatment with an EGFR TKI.

In a Korean study of 90 consecutive NSCLC patients treated with gefitinib monotherapy, the response rate was $14 \%(10 / 73)$ in EGFR wild type and 65\% (11/17) in EGFR mutant tumors, respectively. Of patients who responded, 48\% were EGFR wild type and 52\% were EGFR mutant (Han et al. 2005). A similar observation has been made in patients who respond to erlotinib (Johnson et al. 2004; Pao et al. 2004). 
The impact of EGFR mutations on survival has been analyzed retrospectively in samples from three randomized trials. Two of these were negative trials (TRIBUTE/erlotinib [Eberhard et al. 2005] and INTACT2/gefitinib [Bell et al. 2005a]), where an EGFR TKI was combined with chemotherapy in first-line lung cancer therapy. In both trials there were increased tumor response rates in patients with EGFR mutant tumors that were in the EGFR TKI treatment arm (statistically significant in TRIBUTE and a trend in INTACT-2). However, there was no evidence of a statistically significant treatment effect of mutation status on either progression-free survival or survival. In both studies, patients with EGFR mutated tumors had a better prognosis, regardless of the therapy arm. In BR.21, a monotherapy trial that showed a positive survival advantage in the overall patient population, EGFR mutation status was associated neither with an overall survival benefit, nor with a better prognosis (Tsao et al. 2005). Interestingly, data from an underpowered, and as yet unconfirmed, study suggest that specific EGFR mutations may have unique clinical characteristics, as EGFR TKI-treated patients with exon-19 deletion mutations had longer median survival than patients with the L858R point mutation (34 months versus 8 months) (Riely et al. 2006). This observation should be considered in future analysis of data from clinical trials.

Some patients with tumors bearing EGFR mutations, who have progressed on erlotinib or gefitinib therapy, have been shown to contain an additional EGFR mutation. This secondary mutation in exon 20 leads to substitution of methionine for threonine at position 790 (T790M) in the kinase domain (Pao et al. 2005a). An analogous mutation (T315I) has been observed in the ABL kinase in association with acquired resistance to imatinib (Branford et al. 2002), suggesting that this may be a common therapyassociated TKI escape mechanism in tumors with activating mutations in the tyrosine kinase domain. The emergence of additional mutations on therapy suggests the tumor is dependent on activation of the EGFR pathway for its survival and growth. Interestingly, susceptibility to inherited NSCLC may be associated with the germ-line transmission of the T790M mutation, suggesting that altered EGFR signaling is also important in the genetic susceptibility to lung cancer (Bell et al. 2005a).

\section{INCREASED EGFR GENE COPY NUMBER APPEARS TO BE THE MOLECULAR MARKER THAT IS MOST POSITIVELY PREDICTIVE FOR EGFR TKI SURVIVAL BENEFIT}

EGFR gene copy number has been studied as a predictive marker for patients treated with EGFR inhibitors, on the assumption that increased gene copy number, and/or amplification, indicates tumor dependency on the EGFR pathway (Cappuzzo et al. 2005; Hirsh et al. 2005a). EGFR copy number was assessed by FISH in both BR.21 and ISEL (Hirsh et al. 2005b) and correlated with clinical outcome. Greater survival benefit was seen in the EGFR fluorescence in situ hybridization (FISH)-positive (amplification and high polysomy) patients compared with EGFR FISH-negative patients (Fig. 1). Current information indicates that a positive EGFR FISH test is the best single molecular marker for prediction of clinical benefit of erlotinib monotherapy. Whereas some EGFR FISH-negative patients may respond to erlotinib therapy, a negative EGFR FISH test indicates less likelihood of a clinical benefit. The predictive value of FISH testing is being further assessed prospectively in a number of ongoing randomized phase III trials.

\section{EGFR PROTEIN EXPRESSION BY IMMUNOHISTOCHEMISTRY AND CLINICAL BENEFIT}

In general, EGFR protein expression by immunohistochemistry (IHC) has not been as reliable a predictor of clinical benefit (Table 1) as FISH. In BR.21 and Tribute, EGFR protein expression was assessed by IHC using the Dako Cytomation EGFR pharmDx ${ }^{\text {ru }}$ kit. Univariate analysis of EGFR protein expression in BR.21 showed that survival was prolonged in erlotinib versus the placebo group. However, EGFR IHC positivity was not a statistically significant covariate when a multivariate analysis was performed.

Performance of EGFR IHC is dependent on the antibody used, tissue fixation, and storage time of tissue sections prior to staining (Atkins et al. 2004). The last two variables, fixation and storage time, were not standardized in either study, which could have had an impact on the outcome of the analysis. Control of the key variables that affect perfor-

Table 1. Predictive Value of IHC for a Survival Benefit in BR.21, TRIBUTE, and ISEL

\begin{tabular}{llll}
\hline & BR.21 & TRIBUTE & ISEL \\
\hline & $\begin{array}{l}\text { Erlotinib monotherapy } \\
\text { 2nd / 3rd line }\end{array}$ & $\begin{array}{l}\text { Erlotinib with chemo }(\mathrm{CP}) \\
1 \text { st line }\end{array}$ & $\begin{array}{l}\text { Gefitinib monotherapy } \\
\text { 2nd / 3rd line }\end{array}$ \\
& 731 & 1079 & 1692 \\
Number of subjects & $326(44.6 \%)$ & $344(31.9 \%)$ & $379(22.4 \%)$ \\
Number of patients tested & HR for overall survival & & 0.86 \\
HR for overall survival & 0.73 & 1.00 & $(95 \% \mathrm{CI}=0.76-0.99)$ \\
All subjects & $(95 \% \mathrm{CI}=0.61-0.86)$ & $(95 \% \mathrm{CI}=0.86-1.16)$ & 0.77 \\
& 0.68 & 1.27 & $(95 \% \mathrm{CI}=0.56-1.08)$ \\
IHC positive & $(95 \% \mathrm{CI}=0.49-0.94)$ & $(95 \% \mathrm{CI}=0.95-1.71)$ & 1.57 \\
& $0.93 *$ & 1.02 & $(95 \% \mathrm{CI}=0.86-2.87)$ \\
\hline
\end{tabular}



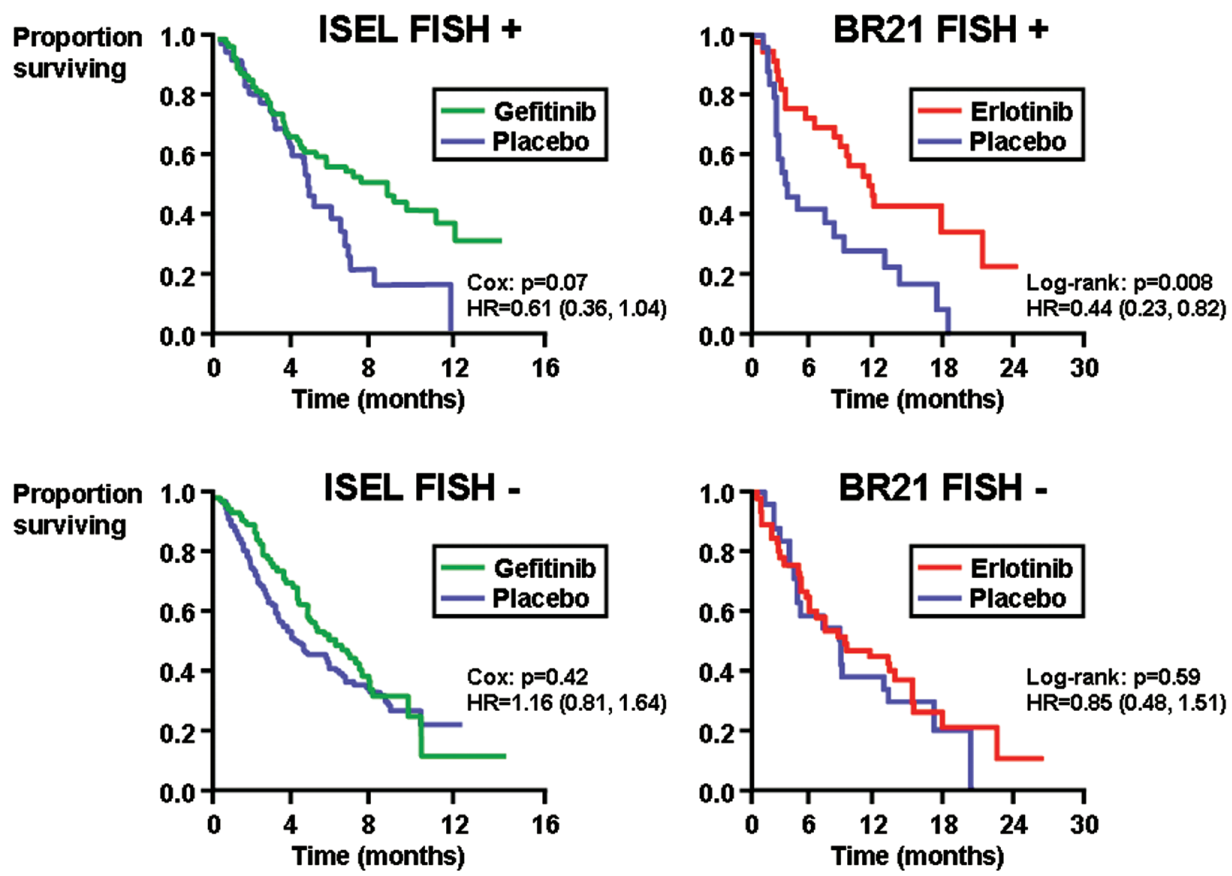

Figure 1. EGFR FISH and survival outcome in patients treated with single agent erlotinib or gefitinib.

mance of EGFR IHC should be incorporated in all ongoing prospective studies that include EGFR IHC testing.

\section{KRAS MUTATIONS, WHICH ARE ASSOCIATED WITH SMOKING HISTORY, SELECT FOR A POPULATION OF PATIENTS THAT DO NOT APPEAR TO BENEFIT FROM EGFR TKI THERAPY}

The RAS/MAPK pathway is a major signaling network that links EGFR activation to cell proliferation and survival (Atkins et al. 2004). Mutations in downstream effectors of EGFR signaling could lead to resistance to EGFR inhibitors (Yarden and Sliwkowski 2001; Bianco et al. 2003). In NSCLC, the most frequently reported alteration in EGFR signaling pathways is mutation of the KRAS gene (Huncharek et al. 1999; Nelson et al. 1999; Ahrendt et al. 2001; Broermann et al. 2002; Keller et al. 2002; Rajagopalan et al. 2002; Grossi et al. 2003; She et al. 2003). KRAS mutations occur in approximately $20 \%$ of NSCLC, are consistently associated with smoking (Ahrendt et al. 2001), and have been associated with poor prognosis (Graziano et al. 1999; Huncharek et al. 1999; Nelson et al. 1999; Schiller et al. 2001; Broermann et al. 2002; Keller et al. 2002; Rajagopalan et al. 2002; Grossi et al. 2003). Because EGFR and KRAS function sequentially in the MAPK signaling pathway, activating mutations in these two molecules might be functionally redundant. Consistent with this hypothesis, in the large majority of NSCLC tumors examined to date, EGFR and KRAS mutations were mutually exclusive (Eberhard et al. 2005; Tam et al. 2006).
Analysis of response rate in NSCLC patients with either erlotinib or gefitinib suggests that KRAS mutations were associated with a lack of tumor regression (Pao et al. 2005b). Retrospective analysis of tumor tissues from $264(25 \%)$ of the patients in TRIBUTE suggests that patients with KRAS mutant tumors experience worse survival when erlotininib was combined with chemotherapy $(\mathrm{HR}=2.06: 95 \% \mathrm{CI}=1.11-3.80)$, compared with those treated with chemotherapy alone $(\mathrm{HR}=1.05: 95 \% \mathrm{CI}=$ 0.73-1.50). This negative interaction appears to be related to expression of EGFR, because in patients in whom both EGFR IHC and KRAS mutation status were available, there was a significant association with poor outcome in patients with KRAS mutant tumors that expressed EGFR (Table 2).

Table 2. Association of KRAS Mutations and EGFR IHC with Survival in TRIBUTE

\begin{tabular}{lll}
\hline \multicolumn{3}{c}{ KRAS mutants and EGFR expression by IHC } \\
\hline \multicolumn{3}{c}{ Erlotinib + chemo Chemo alone } \\
EGFR IHC- \\
$\begin{array}{l}n \\
\text { Median OS (mo) }\end{array}$ & $9.0(3.4,12.9)$ & $12.8(3.3,)$. \\
$\quad(95 \%$ CI $)$ & 0.5507 \\
Log rank P-value & $1.4(0.5,4.3)$ \\
Hazard ratio (95\% CI) & \\
EGFR IHC & \\
$n$ & 12 & $13.5(11.1,15.1)$ \\
Median OS (mo) & $3.4(2.1,4.4)$ \\
$\quad(95 \%$ CI $)$ & $<0.001$ \\
Log rank $p$-value & $4.9(2.1,11.5)$ \\
Hazard ratio (95\% CI) &
\end{tabular}


Downloaded from symposium.cshlp.org on April 25, 2023 - Published by Cold Spring Harbor Laboratory Press

Table 3. Summary of Survival Benefit Observed in Never-Smokers Treated with Erlotinib (BR.21 and TRIBUTE) or Gefitinib (ISEL)

\begin{tabular}{llll}
\hline & BR.21 & TRIBUTE & ISEL \\
\hline & $\begin{array}{l}\text { Erlotinib monotherapy } \\
\text { 2nd / 3rd line }\end{array}$ & $\begin{array}{l}\text { Erlotinib with chemo (CP) } \\
\text { 1st line }\end{array}$ & $\begin{array}{l}\text { Gefitinib monotherapy } \\
\text { 2nd / 3rd line }\end{array}$ \\
Number of subjects & 731 & 1079 & 1692 \\
Number of never-smokers & $146(20.0 \%)$ & $116(10.8 \%)$ & $375(22 \%)$ \\
HR for overall survival & HR for overall survival & & 0.89 \\
All subjects & 0.73 & 1.00 & $(95 \% \mathrm{CI}=0.77-1.02)$ \\
& $(95 \% \mathrm{CI}=0.61-0.86)$ & $(95 \% \mathrm{CI}=0.86-1.16)$ & 0.67 \\
Never-smokers & 0.42 & 0.49 & $(95 \% \mathrm{CI}=0.49-0.92)$ \\
& $(95 \% \mathrm{CI}=0.28-0.64)$ & $(95 \% \mathrm{CI}=0.28-0.85)$ & 0.92 \\
Current/former smokers & 0.87 & 1.11 & $(95 \% \mathrm{CI}=0.79-1.06)$ \\
\hline
\end{tabular}

It is unclear why a negative interaction was observed when erlotinib was administered in combination with chemotherapy in patients whose tumors bore KRAS mutations. It will be important to determine whether this observation is confirmed by retrospective analysis of other randomized controlled trials. Erlotinib has been shown to prolong survival when administered in combination with gemcitabine in pancreatic cancer, a tumor where KRAS mutations are very common.

\section{NEVER-SMOKER STATUS IS CONSISTENTLY PREDICTIVE OF GREATER PATIENT BENEFIT (SURVIVAL AND RESPONSE) FOR ERLOTINIB OR GEFITINIB MONOTHERAPY AND FOR ERLOTINIB IN COMBINATION WITH CHEMOTHERAPY}

Lung cancer patients who have never smoked tobacco have consistently shown a benefit from both erlotinib and gefitinib (Table 3 ). This novel therapeutic observation is unique to EGFR TKIs and has been observed in phase III trials with erlotinib (BR.21) (Shepherd et al. 2005) and gefitinib (ISEL) monotherapy as well as for erlotinib in combination with chemotherapy (TRIBUTE) (Herbst et al. 2005).

Studies have suggested that tumors arising in neversmokers are molecularly and biologically distinct and may be associated with a better prognosis (Sanchez-Cespedes et al. 2001). Never-smokers are more likely to have mutations than smokers in the tyrosine kinase domain of EGFR and almost never harbor mutations in KRAS (Tam et al. 2006). In countries of Southeast Asia, lung cancer is more common in never-smokers than in smokers; thus, racial background, smoking history, and gene mutation status should be considered when designing and interpreting clinical trials in NSCLC with EGFR-TKIs.

\section{SUMMARY AND CONCLUSIONS}

Predictive molecular biomarkers for NSCLC patients treated with EGFR TKIs have largely been determined from studies of small case series and retrospective analyses of subsets of patients from randomized trials; in some cases, these were extracted from negative clinical trials. Overall, the predictive data generated to date can be summarized as follows:

1. EGFR mutations predict dramatic tumor shrinkage but have not been shown to be a good marker for the clinically meaningful endpoint of prolonged survival.

2. EGFR protein expression, as determined by IHC, predicts greater treatment benefit in BR.21 but is not a predictor of benefit in TRIBUTE.

3. High EGFR gene copy number may be the single molecular marker that is most predictive for erlotinib monotherapy.

4. KRAS mutations, which are positively associated with smoking history, select for a subset of patients who do not appear to benefit from erlotinib therapy.

5. Never-smoker status is consistently predictive of greater erlotinib benefit (survival and response) for monotherapy and in combination with chemotherapy.

This and other emerging diagnostic information will aid significantly in designing future studies and, ultimately, should help physicians decide which patients will be most likely to benefit from EGFR TKIs.

\section{ACKNOWLEDGMENTS}

We thank Dr. Fred R. Hirsch of the University of Colorado Cancer Center for providing and granting permission to reproduce Figure 1.

\section{REFERENCES}

Ahrendt S.A., Decker P.A., Alawi E.A., Zhu Yr Y.R., SanchezCespedes M., Yang S.C., Haasler G.B., Kajdacsy-Balla A., Demeure M.J., and Sidransky D. 2001. Cigarette smoking is strongly associated with mutation of the K-ras gene in patients with primary adenocarcinoma of the lung. Cancer 92: 1525 .

Atkins D., Reiffen K.A., Tegtmeier C.L., Winther H., Bonato M.S., and Storkel S. 2004. Immunohistochemical detection of EGFR in paraffin-embedded tumor tissues: Variation in staining intensity due to choice of fixative and storage time of tissue sections. J. Histochem. Cytochem. 52: 893.

Bell D.W., Gore I., Okimoto R.A., Godin-Heymann N., Sordella R., Mulloy R., Sharma S.V., Brannigan B.W., Mohapatra G., Settleman J., and Haber D.A. 2005a. Inherited susceptibility 
to lung cancer may be associated with the T790M drug resistance mutation in EGFR. Nat. Genet. 37: 1315.

Bell D.W., Lynch T.J., Haserlat S.M., Harris P.L., Okimoto R.A., Brannigan B.W., Sgroi D.C., Muir B., Riemenschneider M.J., Iacona R.B., Krebs A.D., Johnson D.H., Giaccone G., Herbst R.S., Manegold C., Fukuoka M., Kris M.G., Baselga J., Ochs J.S., and Haber D.A. 2005b. Epidermal growth factor receptor mutations and gene amplification in non-small-cell lung cancer: Molecular analysis of the IDEAL/INTACT gefitinib trials. J. Clin. Oncol. 23: 8081.

Bianco R., Shin I., Ritter C.A., Yakes F.M., Basso A., Rosen N., Tsurutani J., Dennis P.A., Mills G.B., and Arteaga C.L. 2003. Loss of PTEN/MMAC1/TEP in EGF receptor-expressing tumor cells counteracts the antitumor action of EGFR tyrosine kinase inhibitors. Oncogene 22: 2812.

Branford S., Rudzki Z., Walsh S., Grigg A., Arthur C., Taylor K., Herrmann R., Lynch K.P., and Hughes T.P. 2002. High frequency of point mutations clustered within the adenosine triphosphate-binding region of $\mathrm{BCR} / \mathrm{ABL}$ in patients with chronic myeloid leukemia or Ph-positive acute lymphoblastic leukemia who develop imatinib (STI571) resistance. Blood 99: 3472 .

Broermann P., Junker K., Brandt B.H., Heinecke A., Freitag L., Klinke F., Berdel W.E., and Thomas M. 2002. Trimodality treatment in stage III non small cell lung carcinoma: Prognostic impact of K-ras mutations after neoadjuvant therapy. Cancer 94: 2055.

Cappuzzo F., Hirsch F.R., Rossi E., Bartolini S., Ceresoli G.L., Bemis L., Haney J., Witta S., Danenberg K., Domenichini I., Ludovini V., Magrini E., Gregorc V., Doglioni C., Sidoni A., Tonato M., Franklin W.A., Crino L., Bunn P.A., Jr., and Varella-Garcia M. 2005. Epidermal growth factor receptor gene and protein and gefitinib sensitivity in non-small-cell lung cancer. J. Natl. Cancer Inst. 97: 643.

Dazzi H., Hasleton P.S., Thatcher N., Barnes D.M., Wilkes S., Swindell R., and Lawson R.A. 1989. Expression of epidermal growth factor receptor (EGF-R) in non-small cell lung cancer. Use of archival tissue and correlation of EGF-R with histology, tumour size, node status and survival. Br. J. Cancer 5: 746.

Eberhard D.A., Johnson B.E., Amler L.C., Goddard A.D., Heldens S.L., Herbst R.S., Ince W.L., Janne P.A., Januario T., Johnson D.H., Klein P., Miller V.A., Ostland M.A., Ramies D.A., Sebisanovic D., Stinson J.A., Zhang Y.R., Seshagiri S., and Hillan K.J. 2005. Mutations in the epidermal growth factor receptor and in KRAS are predictive and prognostic indicators in patients with non-small-cell lung cancer treated with chemotherapy alone and in combination with erlotinib. $J$. Clin. Oncol. 23: 5900.

Graziano S.L., Gamble G.P., Newman N.B., Abbott L.Z., Rooney M., Mookherjee S., Lamb M.L., Kohman L.J., and Poiez B.J. 1999. Prognostic significance of K-ras codon 12 mutations in patients with resected stage I and II non-smallcell lung cancer. J. Clin. Oncol. 17: 668.

Grossi F., Loprevite M., Chiaramondia M., Ceppa P., Pera C., Ratto G.B., Serrano J., Ferrara G.B., Costa R., Boni L., and Ardizzoni A. 2003. Prognostic significance of K-ras, p53, bci2, PCNA, CD34 in radically resected non-small cell lung cancers. Eur. J. Cancer 39: 1242.

Han S.W., Kim T.Y., Hwang P.G., Jeong S., Kim J., Choi I.S., Oh D.Y., Kim J.H., Kim D.W., Chung D.H., Im S.A., Kim Y.T., Lee J.S., Heo D.S., Bang Y.J., and Kim N.K. 2005. Predictive and prognostic impact of epidermal growth factor receptor mutation in non-small-cell lung cancer patients treated with gefitinib. J. Clin. Oncol. 23: 2493.

Herbst R.S., Prager D., Hermann R., Fehrenbacher L., Johnson B.E., Sandler A., Kris M.G., Tran H.T., Klein P., Li X., Ramies D., Johnson D.H., Miller V.A.; TRIBUTE Investigator Group. 2005. TRIBUTE: A phase III trial of erlotinib hydrochloride (OSI-774) combined with carboplatin and paclitaxel chemotherapy in advanced non-small-cell lung cancer. $J$ Clin Oncol. 23: 5892.

Higgins B., Kolinsky K., Smith M., Beck G., Rashed M., Adames V., Linn M., Wheeldon E., Gand L., Birnboeck H., and Hoffmann G. 2004. Antitumor activity of erlotinib (OSI774 , Tarceva) alone or in combination in human non-small cell lung cancer tumor xenograft models. Anticancer Drugs 5:503.

Hirsch F.R., Varella-Garcia M., and Bunn P.A., et al. 2005a. Molecular analysis of EGFR gene copy number, EGFR expression, and Akt activation in advanced non-small-cell lung cancer (aNSCLC) treated with gefitinib or placebo (ISEL trial). In 17th Annual AACR-NCI-EORTC International Conference on Molecular Targets and Cancer Therapeutics, Philadelphia, Pennsylvania. Abstract A268.

Hirsch F.R., Varella-Garcia M., McCoy J., West H., Xavier A.C., Gumerlock P., Bunn P.A., Jr., Franklin W.A., Crowley J., Gandara D.R., and Southwest Oncology Group. 2005b. Increased epidermal growth factor receptor gene copy number detected by fluorescence in situ hybridization associates with increased sensitivity to gefitinib in patients with bronchioloalveolar carcinoma subtypes: A Southwest Oncology Group Study. J. Clin. Oncol. 23: 6838.

Huncharek M., Muscat J., and Geschwind J.F. 1999. K-ras oncogene mutation as a prognostic marker in non-small cell lung cancer: A combined analysis of 881 cases. Carcinogenesis 20: 1507 .

Johnson B.E., Lucca J., Rabin M.S., Lynch T.J., Ostler P., Skarin A.T., Temel J., Liu G., and Janne P.A. 2004. Preliminary results from a phase II study of the epidermal growth factor receptor tyrosine kinase inhibitor erlotinib in patients $>70$ years of age with previously untreated advanced non-small cell lung carcinoma. J. Clin. Oncol. 22: 633. (Abstr. 7080.)

Kaseda S., Ueda M., Ozawa S., Ishihara T., Abe O., and Shimizu N. 1989. Expression of epidermal growth factor receptors in four histologic cell types of lung cancer. J. Surg. Oncol. 42: 16.

Keller S.M., Vangel M.G., Adak S., Wagner H., Schiller J.H., Herskovic A., Komaki R., Perry M.C., Marks R.S., Livingston R.B., and Johnson D.H. 2002. The influence of gender on survival and tumor recurrence following adjuvant therapy of completely resected stages II and IIIa non-small cell lung cancer. Lung Cancer 37: 303.

Lynch T.J., Bell D.W., Sordella R., Gurubhagavatula S., Okimoto R.A., Brannigan B.W., Harris P.L., Haserlat S.M., Supko J.G., Haluska F.G., Louis D.N., Christiana D.C., Settleman J., and Haber D.A. 2004a. Activating mutations in the epidermal growth factor receptor underlying responsiveness of non-small-cell lung cancer to gefitinib. N. Engl. J. Med. 350: 2129.

Lynch T.J., Adjei A.A., Bunn P.A., Jr., DuBois R.N., Gandara D.R., Giaccone G., Govindan R., Herbst R.S., Johnson B.E., Khuri F.R., Perez-Soler R., Rosell R., Rowinsky E.K., Sandler A.B., Scagliotti G.V., Schiller J.H., Shapiro G.I., Socinski M.A., and Hart C.S. 2004b. Novel agents in the treatment of lung cancer: Conference summary statement. Clin. Cancer Res. 10: 4199s.

Nelson H.H., Christiani D.C., Mark E.J., Wiencke J.K., Wain J.C., and Kelsey K.T. 1999. Implications and prognostic value of K-ras mutation for early-stage lung cancer in women. $J$. Natl. Cancer Inst. 91: 2032.

Paez J.G., Janne P.A., Lee J.C., Tracy S., Greulich H., Gabriel S., Herman P., Kaye F.J., Lindeman N., Boggon T.J., Naoki K., Sasaki H., Fujii Y., Eck M.J., Sellers W.R., Johnson B.E., and Meyerson M. 2004. EGFR mutations in lung cancer: Correlation with clinical response to gefitinib therapy. Science 304: 1497.

Pao W. and Miller V.A. 2005. Epidermal growth factor receptor mutations, small-molecule kinase inhibitors, and non-smallcell lung cancer: Current knowledge and future directions. $J$. Clin. Oncol. 23: 2556.

Pao W., Miller V.A., Politi K.A., Riely G.J., Somwar R., Zakowski M.F., Kris M.G., and Varmus H. 2005a. Acquired resistance of lung adenocarcinomas to gefitinib or erlotinib is associated with a second mutation in the EGFR kinase domain. PLoS Med. 2: e73.

Pao W., Wang T.Y., Riely G.J., Miller V.A., Pan Q., Ladanyi M., Zakowski M.F., Heelan R.T., Kris M.G., and Varmus 
H.E. 2005b. KRAS mutations and primary resistance of lung adenocarcinomas to gefitinib or erlotinib. PLoS Med. 2: e17.

Pao W., Miller V., Zakowski M., Doherty J., Politi K., Sarkaria I., Singh B., Heelan R., Rusch V., Fulton L., Mardis E., Kupfer D., Wilson R., Kris M., and Varmus H. 2004. EGF receptor gene mutations are common in lung cancers from "never smokers" and are associated with sensitivity of tumors to gefitinib and erlotinib. Proc. Natl. Acad. Sci. 101: 13306.

Rajagopalan H., Bardelli A., Lengauer C., Kinzler K.W., Vogelstein B., and Velculescu V.E. 2002. Tumorigenesis: RAF/RAS oncogenes and mismatch-repair status. Nature 418: 934.

Riely G.J., Pao W., Pham D., Li A.R., Rizvi N., Venkatraman E.S., Zakowski M.F., Kris M.G., Ladanyi M., and Miller V.A. 2006. Clinical course of patients with non-small cell lung cancer and epidermal growth factor receptor exon 19 and exon 21 mutations treated with gefitinib or erlotinib. Clin. Cancer Res. 12: 839 .

Sanchez-Cespedes M., Ahrendt S.A., Piantadosi S., Rosell R., Monzo M., Wu L., Westra W.H., Yang S.C., Jen J., and Sidransky D. 2001. Chromosomal alterations in lung adenocarcinoma from smokers and non-smokers. Cancer Res. 61: 1309.

She Q.B., Solit D., Basso A., and Moasser M.M. 2003. Resistance to gefitinib in PTEN-null HER-overexpressing tumor cells can be overcome through restoration of PTEN function or pharmacologic modulation of constitutive phosphatidylinositol 3'-kinase/Akt pathway signaling. Clin. Cancer Res. 9: 4340 .

Shepherd F.A., Rodrigues Pereira J., Ciuleanu T., Tan E.H., Hirsh V., Thongprasert S., Campos D., Maoleekoonpiroj S., Smylie M., Martins R., van Kooten M., Dediu M., Findlay B.,
Tu D., Johnston D., Bezjak A., Clark G., Santabarbara P., and Seymour L. 2005. National Cancer Institute of Canada Clinical Trials Group. Erlotinib in previously treated non-smallcell lung cancer. N. Engl. J. Med. 353: 123.

Schiller J.H., Adak S., Feins R.H., Keller S.M., Fry W.A., Livingston R.B., Hammond M.E., Wolf B., Sabatini L., Jett J., Kohman L., and Johnson D.H. 2001. Lack of prognostic significance of $\mathrm{p} 53$ and K-ras mutations in primary resected nonsmall-cell lung cancer on E4592: A laboratory ancillary study on an Eastern Cooperative Oncology Group prospective randomized trial of postoperative adjuvant therapy. J. Clin. Oncol. 19: 448 .

Sordella R., Bell D.W., Haber D.A., and Settleman J. 2004. Gefitinib-sensitizing EGFR mutations in lung cancer activate anti-apoptotic pathways. Science 305: 1163.

Tam I.Y., Chung L.P., Suen W.S., Wang E., Wong M.C., Ho K.K., Lam W.K., Chiu S.W., Girard L., Minna J.D., Gazdar A.F., and Wong M.P. 2006. Distinct epidermal growth factor receptor and KRAS mutation patterns in non-small cell lung cancer patients with different tobacco exposure and clinicopathologic features. Clin. Cancer Res. 12: 1647.

Tamura K. and Fukuoka M. 2005. Gefitinib in non-small cell lung cancer. Expert Opin. Pharmacother. 6: 985.

Tsao M.S., Sakurada A., Cutz J.C., Zhu C.Q., Kamel-Reid S., Squire J., Lorimer I., Zhang T., Liu N., Daneshmand M., Marrano P., da Cunha Santos G., Lagarde A., Richardson F., Seymour L., Whitehead M., Ding K., Pater J., and Shepherd F.A. 2005. Erlotinib in lung cancer: Molecular and clinical predictors of outcome. N. Engl. J. Med. 353: 133.

Yarden Y. and Sliwkowski M.X. 2001. Untangling the ErbB signalling network. Nat. Rev. Mol Cell. Biol. 2: 127. 


\section{$8_{8}^{\infty} \mathrm{CSH} \&$ Cold Spring Harbor Symposia SYMPOSIA on Quantitative Biology}

\section{Predicting Clinical Benefit in Non-Small-Cell Lung Cancer Patients Treated with Epidermal Growth Factor Tyrosine Kinase Inhibitors}

L.C. AMLER, A.D. GODDARD and K.J. HILLAN

Cold Spring Harb Symp Quant Biol 2005 70: 483-488

Access the most recent version at doi:10.1101/sqb.2005.70.048

References This article cites 39 articles, 16 of which can be accessed free at: http://symposium.cshlp.org/content/70/483.full.htmI\#ref-list-1

\section{License}

Email Alerting Receive free email alerts when new articles cite this article - sign up in Service the box at the top right corner of the article or click here. 